\title{
Zemljepisna lastna imena v Večeslavcih
}

\author{
Mihaela Koletnik - Zdenka Holsedl
}

\begin{abstract}
V prispevku so predstavljena zemljepisna lastna imena naselja Večeslavci v Prekmurju. V njih se odražajo glasoslovne in oblikoslovne značilnosti prekmurskega goričkega podnarečja. Glede na motivacijsko podstavo so razvrščena $\mathrm{v}$ pomenske skupine. Večinoma so izvorno slovenska, v podstavi nekaterih poimenovanj pa so tudi v časovno različnih jezikovnozgodovinskih obdobjih prevzete besede iz stičnih jezikov.
\end{abstract}

\section{Toponyms in Večeslavci}

This article presents toponyms in the settlement of Večeslavci in Prekmurje. These reflect phonological and morphological characteristics of the Goričko subdialect of Prekmurje. They are sorted into semantic groups by their motivational basis. The majority are Slovenian in origin, and the bases of some expressions are also words borrowed from contact languages in various historical linguistic periods.

\section{Uvod}

V razpravi so predstavljena narečna zemljepisna lastna imena v Večeslavcih, razloženem goričkem naselju na obeh straneh Ledave ob cesti Gederovci-Sotina, ki je bilo z imenom Wenchezlaufolua (Venčeslavova vas) prvič zapisano v listini iz leta 1365.

Izraz toponim je »lastno ime kraja ali kakega drugega dela zemeljskega površja, zemljepisno ime« (SSKJ: 1409). Zemljepisna imena preučuje toponomastika (krajevno imenoslovje), ki je del onomastike (imenoslovja). Toponomastika se ukvarja z zemljepisnimi poimenovanji nežive, poseljene ali neposeljene zemljepisne pojavnosti na kakem področju (Unuk 2004: 194). Gre za nazive večjih ozemeljskih naravnih in upravnih celot, manjše objekte pa preučuje mikrotoponimija. Mikrotoponimi ${ }^{1}$ ali ledinska imena, ${ }^{2}$ tj. imena njiv, travnikov, gozdov (SSKJ: 295, 551) - po Čopu $(2002: 98,99)$ mednje prištevamo tudi imena pašnikov, dolin, sotesk, tesni, kraških jam, imena poti in njihovih delov -, spadajo med nenaselbinska

${ }^{1}$ Iz gr. onoma 'ime', topos 'kraj, mesto, prostor, pokrajina, okolica, dežela, ozemlje', mikros 'majhen', tj. mala zemljepisna imena (Šekli 2007: 50).

2 V slovenščini se uporabljata še izraza terenska (Čop 2002: 98) in zemljiška imena (Unuk 2004: 194). 
zemljepisna imena. Šekli (2008: 13) jih glede na predmet poimenovanja deli v šest skupin: (1) obdelovalne zemeljske površine za gojenje kulturnih rastlin (agronimi): polja, njive, (2) travniki, senožeti, pašniki, (3) gozdovi (gozdna imena), (4) vodne površine (vodna ledinska imena), (5) vzpetine (gorska ledinska imena), (6) poti in njihovi deli. Isti avtor ugotavlja, da je »razmejitev med vodnimi ledinskimi imeni, gorskimi ledinskimi imeni in ledinskimi imeni poti in njihovih delov na eni strani ter vodnimi imeni, gorskimi imeni in imeni poti in njihovih delov na drugi [...] pogosto zelo težavna. Merilo razmejitve med npr. gorskimi ledinskimi imeni in gorskimi imeni bi bilo lahko to, da gorska ledinska imena poimenujejo dele gorske površine, medtem ko gorska imena poimenujejo celotno vzpetino.« (Šekli 2007: $50-51)$

Ledinska imena, verjetno nastala iz potrebe po natančnem razlikovanju in določanju vaškega ozemlja, so se ohranila v glavnem prek ustnega izročila. Nekatera so bila tudi zapisana, saj so jih od srede 18. do prve polovice 19. stoletja, ko so na podlagi natančne izmere zemljišč nastale katastrske mape (terezijanski kataster /1748-1756/, jožefinski kataster /1785-1789/, franciscejski kataster /1818-1828/), vanje vnašali državni uradniki. Ozemlje Prekmurja v času vladanja Franca I. ni bilo zajeto v katastrsko izmero. Tako je najstarejša katastrska mapa za Prekmurje mnogo mlajša od franciscejske (po letu 1860) ter pomanjkljiva, brez pripadajočih parcelnih protokolov (Ilešič 1950: 12-13).

Zemljepisna imena smo zbirali na terenu, pri čemer so bili naš (ustni) vir domačini. Od pisnih virov smo pregledali (1) katastrske mape in načrte ter topografski načrt za katastrsko občino Večeslavci; ker so kartografski viri prostorsko omejeni, vsebujejo samo najpomembnejša ledinska imena, ki poimenujejo večje zemeljske površine; (2) GERK-e, tj. grafične enote rabe zemljǐš kmetijskega gospodarstva; ${ }^{3}$ (3) jožefinske vojaške zemljevide, tj. najstarejše podrobne zemljevide slovenskih dežel s prevladujočimi slovenskimi zapisi toponimov, ki so nastajali v letih 17631887. Ozemlje Prekmurja, ki je v času izmere spadalo pod Ogrsko, so kartirali in opisali leta 1874. Barvnim zemljevidom, izdelanim v merilu $1: 28.800$ in razdeljenim na t. i. sekcije, ${ }^{4}$ so bili dodani podrobni topografski opisi. Večeslavci so na zemljevidih zapisani s krajevnim imenom Sessldorf oder Vecsislavecz (Rajšp - Serše 2001: 8; I-6), ledinskih imen pa ne najdemo, čeprav je s kart nazorno razvidna podoba pokrajine in čeprav se $\mathrm{v}$ opisu $\mathrm{h}$ karti ${ }^{5}$ omenjajo: potok $\mathrm{v}$ dolini, ki ob močnem deževju preplavi velik del doline, gozd desno od Sv. Jurija, ki je gosto porasel z visokimi bukvami in hrasti, travniki, ki so le tu in tam močvirni, ter poti v hribe, ki so poškodovane in vedno težavne (navedeno po Rajšp - Serše 2001: 7).

3 GERK je strnjena površina kmetijskega ali gozdnega zemljišča $\mathrm{z}$ isto vrsto dejanske rabe, ki je v uporabi enega kmetijskega gospodarstva.

4 Obravnavano naselje je uvrščeno v sekcijo I-6.

5 Pomembno dopolnilo h kartam so opisi pokrajine in njenih značilnosti, ki jih kartografsko ni bilo mogoče dovolj natančno prikazati. 


\section{$1 \quad$ Nabor zemljepisnih imen}

Zbirka imen je slovarsko urejena; pri veččlenskih imenih je kot iztočnica upoštevan jedrni del imena. Geslo je sestavljeno iz poknjižene iztočnice, ki ji za ločevalnim znakom || sledijo v slovenski dialektološki transkripciji zapisano in onaglašeno narečno ime v osnovni (prvi in drugi, če ta obstaja) slovarski obliki in mestniku ter slovnični podatki o besedi. Temu zapisu sledijo kategorija imena (hdn, mtn, tpn) in etimološki podatki iz DLS, ESSJ I-V, Snoj 2003 in SVI I-II. Zvezdica * označuje, da kazalka ni uresničena kot zemljepisno ime.

Bojna || 'Bọna -e, v'Bojni ž, mtn gozda, njive in travnika; ime ustreza apelativu bôjjna (Plet. I: 42); na tem območju so v času druge svetovne vojne potekali boji; ostanki treh bunkerjev so vidni še danes.

Borovica || Bo'ro:jca -e, v Bo'ro:jci ž, tpn zaselka in mtn njive ter gozda; ime je izpeljano iz dnd bòr 'Pinus silvestris', svojilne pripone -ov in imenovalniške -ica.

\section{*brajda $\Rightarrow$}

Za brajdami || Za b'ra:jdami, mtn njive; v imenu se ohranja izposojenka iz furl. bràida 'zaprto obdelano zemljišče, na katerem gojijo trto', to pa iz ben. it. bràida 'majhna posest, majhna najemna posest'; beseda je langob. izvora (ESSJ I: 37).

Breg \| B're:ik, Bri'ga:, na B're:igi m, mtn travnika; ime ustreza knjiž. apelativu brég 'nagnjen svet, strmina'.

Cucekov breg || 'Cücekof b're:ik, 'Cücekovoga bri'ga:, na 'Cücekovon b're:igi m, mtn travnika; svojilni pridevnik je iz hišnega imena.

Frančev breg || F'ro:ncof b're:ik, F'ro:ncovoga bri'ga:, na F'ro:ncovon b're:igi $\mathrm{m}, \mathrm{mtn}$ njive, travnika in sadovnjaka; svojilni pridevnik je iz osebnega imena lastnika.

Pintarjev Breg || 'Pi:ntarof B're:ik, 'Pi:ntarovoga Bri'ga:, na 'Pi:ntarovon $B^{\prime} r e:$ igi m, tpn zaselka; svojilni pridevnik je iz hišnega imena Píntar, to pa iz imena poklica iz nem. Fassbinder 'sodar'.

Rakov Breg || 'Råkof B're:ịk, 'Råkovoga Bri'ga:, na 'Råkovon B're:igi m, tpn zaselka; svojilni pridevnik je iz priimka lastnika.

Sikašev Breg || 'Sikašof B're:îk, 'Sikašovoga Bri'ga:, na 'Sikašovon B're:ingi m, tpn zaselka; svojilni pridevnik je iz hišnega imena.

Na bregu \|Na b're:igi, mtn njive in travnika.

Britof \| B'rü:ittof -ova, na B'rü:itovi m, mtn njiv in travnikov; ime ustreza apelativu britof 'pokopališče', izposojenki iz stvnem. frïthof, srvnem. vrïthof, nem. Friedhof (ESSJ I: 45).

Buroševo || 'Bü:rošovo -oga, na 'Bü:rošovon s, mtn njive; ime posesti je izpeljano iz hišnega imena.

Cerkveno || Cerk'veno -oga, na Cerk'venon s, mtn njive; ime je izpeljano iz apelativa cérkev in pomeni nekdanjo cerkveno posest.

Cuckovo || 'Cü:cekovo -oga, na 'Cü:cekovon s, mtn njive in travnika; ime je tvorjeno iz hišnega imena posestnika in svojilne pripone -ov.

Cuncelj || 'Cüncel -cla, na 'Cüncli m, mtn njive, travnika, sadovnjaka in gozda; ime ni jasno. 
Curek || 'Cürek -rka, pr 'Cürki m, hdn manjšega potoka; v imenu se ohranja apelativ cúrek 'tok, izvir' < curéti 'počasi teči' (SVI I: 106).

Črete $\| \check{C}^{\prime}$ rẹte, $f \check{C}^{\prime}$ rẹtaj ž mn., mtn travnika; ime ustreza množinski obliki apelativa čréta 'močviren nižinski svet, porasel s travo in nizkim grmičjem', ki je pogosta toponimična baza v južnoslovanski toponomastiki (SVI I: 121).

Dedijevo || 'De:idijovo -oga, na 'De:idijovon $\mathrm{s}$, mtn njive; ime je izpeljano iz apelativa dédi in svojilne pripone -ov.

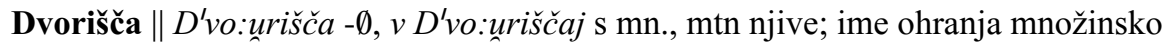

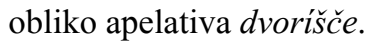

*Flikaš $\Rightarrow$

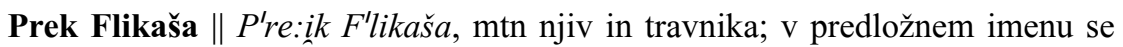
ohranja hišno ime Flíkaš.

Frčkovo \| 'Frčkovo -oga, na 'Frčkovon s, mtn njive in travnika; ime posesti je iz hišnega imena.

Gomblice \|| 'Go:mblce $-\emptyset, v^{\prime}$ Gomblgcaj ž mn., mtn njiv, travnikov in sadovnjaka; ime, verjetno nastalo po značilni obliki zemljišča, ki je $\mathrm{v}$ primerjavi z okoliško parcelizacijo kroglaste oblike, je morda izpeljano iz nar. apelativa gómbleg, gómblek 'brezov cvet' (ESSJ I: 160), izposojenke iz madž. gombolyag 'krogla, klobčič'.

*gomila $\Rightarrow$

Na gomili || Na go'müli, mtn njiv, travnikov in gozda; ime ustreza knjiž. apelativu gomila 'kup, kup prsti, grob'.

*gorica $\Rightarrow$

Horvatove gorice \| Xor'va:tove go'rice, Xor'va:tovij go'ri:ic, $f$ Xor'va:tovij go'ricaj ž mn., mtn vinograda; v imenu se ohranja apelativ goríca 'mala gora, najvišji trg v kraju; vinograd', manjšalnica na -ica iz góra (ESSJ I: 162, pod góra).

Kolmankove gorice \| Kol'mo:nkove go'rice, Kol'mọ:nkovij go'ri:ic, $f$ Kol'mo:nkovij go'ricaj ž mn., mtn vinograda; svojilni pridevnik je iz priimka posestnika.

Lulikove gorice || 'Lü:likove go'rice, 'Lü:likovij go'ri:ịc, v 'Lü:likovij go'ricaj ž $\mathrm{mn}$., mtn vinograda; svojilni pridevnik je iz hišnega imena.

Pintarjeve gorice || 'Pi:ntarove go'rice, 'Pi:ntarovij go'ri:ic, $f$ 'Pi:ntarovij go'ricaj ž mn., mtn vinograda; svojilni pridevnik je iz hišnega imena Píntar, to pa iz imena poklica iz nem. Fassbinder 'sodar'.

Roganove gorice || 'Ro:ganove go'rice, 'Rọ:ganovij go'ri:ic, $v$ 'Ro:ganovij go'ricaj ž mn., mtn vinograda; svojilni pridevnik je iz priimka posestnika. Vaniševe gorice || 'Va:nišove go'rice, 'Va:nišovij go'ri:icc, v'Va:nišovij go'ricaj ž $\mathrm{mn}$., mtn vinograda; svojilni pridevnik je iz hišnega imena.

*graba $\Rightarrow$

Balaževa Graba || Balla:žova G'råba, Ba'la:žove G'råbe, v Balla:žovoj G'råbi ž, tpn zaselka, tudi mtn njive in travnika $\mathrm{v}$ tem zaselku; $\mathrm{v}$ imenu se ohranja apelativ grába 'jarek, prekop' iz stvnem. grabo, srvnem. grabe (ESSJ I: 167; SVI I: 192). 
Cučeva Graba || 'Cücova G'råba, 'Cücove G'råbe, f'Cücovoj G'råbi ž, tpn zaselka, tudi mtn njive, travnika in gozda $\mathrm{v}$ tem zaselku; svojilni pridevnik je iz hišnega imena.

Marčeve grabe || 'Mårčove g'råbe, 'Mårčovij g'ra:p, v 'Mårčovij g'råbaj ž mn., mtn njiv, travnika, sadovnjaka in gozda; svojilni pridevnik je iz hišnega imena.

Mencingarjeve Grabe \| 'Mẹ:ncingarove G'råbe, 'Mẹ:ncingarovij G'ra:p, v 'Mẹ:ncingarovij G'råbaj ž mn., tpn zaselka, tudi mtn njiv, travnikov, sadovnjaka, vinograda in gozda v tem zaselku; svojilni pridevnik je iz priimka.

Perševe Grabe || 'Peršove G'råbe, 'Peršovij G'ra:p, f'Peršovij G'råbaj ž mn., tpn zaselka, tudi mtn njiv, travnika, sadovnjaka in gozda v tem zaselku; svojilni pridevnik je iz hišnega imena.

Sabolove grabe || Sa'bo:ulove g'råbe, Sa'bo:ulovij g'ra:p, f Sa'bo:ulovij g'råbaj ž mn., mtn travnikov; svojilni pridevnik je iz hišnega imena.

Za grabami || Za g'råbami, mtn njive.

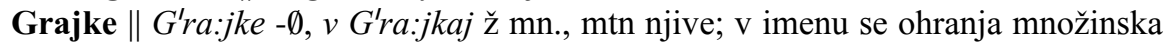
oblika apelativa grâjka 'die Umzäunung' (Plet. I: 243); najstarejši splošnoslovanski pomen glagola gradíti, ohranjen v ogradíti, ográjati, ograjeváti, je ‘postavljati ograjo' (ESSJ I: 168).

Gres \| G'rẹ:is -a, na G're:isi v tem zaselku; v imenu se ohranja apelativ grés iz srvnem. griez 'pesek, prod, grobo mleto žito'; pomen 'pesek' je znan samo na severovzhodu slovenskega jezikovnega prostora (ESSJ I: 175).

*jablana $\Rightarrow$

Pri jablanah || $P r$ క̌ab'la:naj, mtn njive; v predložnem imenu se ohranja dnd jáblan(a) 'Pirus malus'.

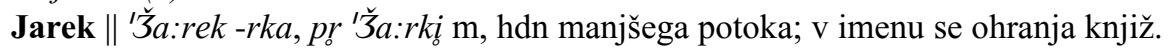
apelativ járek 'v zemljo narejena ožja podolgovata vdolbina'; járek je pogosto ime manjših vodnih tokov, predvsem umetno izkopanih (SVI I: 234).

Pri Jarku \|Pr '̌̌a:rki, mtn travnika.

Jeruzalem || Ge'ru:zalen - $a, v$ Ge'ru:zalemi m, tpn zaselka; ime je nastalo s prenosom prispodobe Jezusovega trpljenja v Jeruzalemu; med leti 1941-1945 je prav iz tega vaškega zaselka odšlo v vojno največ moških; tudi mtn njiv, travnikov, gozda, sadovnjaka in vinograda $v$ tem zaselku.

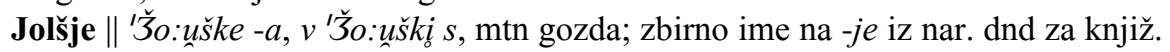
jélša 'Alnus'; Bezlaj (ESSJ I: 226; SVI II: 60) navaja, da sta obliki olša (< pslovan. *òlbša) in jelša (< pslovan. *jèlbša) sporadično razširjeni po vsem slovenskem ozemlju, prva zlasti na Koroškem, vzhodnem Štajerskem in v Prekmurju. Celčevo jolšje || 'Ce:ucovo '̌̌o:uške, 'Cẹ:ucovoga 'క̌o:uška, f'Ce:ucovon 'žo:uški s, mtn gozda; svojilni pridevnik je iz priimka lastnika.

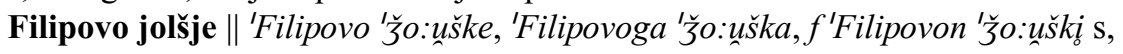
mtn gozda; svojilni pridevnik je iz osebnega imena.

Jolšje pri Flikašu || 'گ̌o:uš̌ke pr F'likašs s, mtn gozda; v krajevnem določilu se ohranja hišno ime. 
Popovo jolšje || 'Popovo 'žo:uške, 'Popovoga 'žo:uška, f'Popovon 'žo:uški s, $\mathrm{mtn}$ gozda; svojilni pridevnik je s svojilno pripono -ov izpeljan iz apelativa pòp 'duhovnik', izposojenke iz stvnem. pfaffo 'duhovnik'; beseda je gr. izvora (ESSJ III: 86).

Rajsarjevo jolšje || 'Ra:jsarovo 'žo:uške, 'Ra:jsarovoga 'క̌o:ǔska, v'Ra:jsarovon '̌̌o:uški s, mtn gozda; svojilni pridevnik je iz hišnega imena.

Jožkino || 'گ̌o:uškino -oga, na 'گ̌o:uškinon s, mtn gozda; ime posesti je tvorjeno iz hišnega imena, to pa iz osebnega imena lastnika.

Kalvarija || Kal'va:rija -e, na Kal'va:rijj ž, mtn travnikov in gozda na manjši vzpetini; ime ustreza apelativu kalvárija 'veliko trpljenje, bolečina'.

Krčevine \| Kr'čóo:nje, na Kr'čco:njaj ž mn., mtn njiv; v imenu se ohranja množinska oblika knjiž. apelativa krčevína 'zemljišče, s katerega je odstranjeno grmovje, drevje, zlasti gozd', ki je razširjen zlasti v vzhodnem slovenskem jezikovnem prostoru (Štajerska, Dolenjska) (SVI I: 301).

$*$ križ $\Rightarrow$

Pri križu \| $\operatorname{Pro} k^{\prime} r i: i \check{z} i$, mtn njive; v predložnem imenu se ohranja apelativ križ.

*krtovinjak $\Rightarrow$

Na krtovinjaku || Na krto'fi:njeki, mtn travnika; v imenu se ohranja nar. oblika apelativa krtovinjak 'krtina' (prim. Novak 1996: 67).

Ledava || 'Ledava -e, pr 'Ledavi ž, hdn potoka (levi pritok Mure); 1208 ad aquam Lyndwa, 1232 ad fluvium Lyndua, ad alium fluvium Lindua, 1265 Chernech iuxta Linduam, 1323 inter fluvios Lyndua et Mura, 1339 prope fluuim Lindua, 1366 iuxta fluuium Lindwa, 1381 iuxta fluuium Lyndua, 1389 a parte fluuij Lynduauize (Zelko 1982: 54); etimolgija imena ni dokončno pojasnjena. ${ }^{6}$

Pri Ledavi \| $P r$ 'Ledavi, mtn njiv in travnikov; ime posesti je povzeto po vodnem imenu.

Ledavsko || 'Ledafsko -oga, na 'Ledafskon s, mtn njive; ime posesti je v zvezi z vodnim imenom Ledava.

$*$ Ies $\Rightarrow$

Barin les || 'Ba:rin 'le:is, 'Ba:rinoga li'sa:, v 'Ba:rinon 'le:isi m, mtn gozda; v imenu se ohranja knjiž. apelativ lés < pslovan. *lêsb z domnevnim prvotnim pomenom *'zapuščeno, ne več obdelano zemljišče, na katerem je pognalo grmičevje' (SES: 352); svojilni pridevnik je izpeljan iz hišnega imena, to pa iz osebnega imena Bára.

Batjanov les || 'Båtjanof 'le:is, 'Båtjanovoga li'sa:, v'Båtjanovon 'le:irsi m, mtn gozda; svojilni pridevnik je izpeljan iz hišnega imena.

Debeljakov les || Debe'la:kof'le:is, Debe'la:kovoga li'sa:, v Debe'la:kovon 'le:isi $\mathrm{m}$, mtn gozda; svojilni pridevnik je izpeljan iz hišnega imena.

6 Kelemina je prvi zapis Linddolves rekonstruiral v *Lindolfesbach, kar bi dalo sloven. Ledava, Lendava in nem. *Lindenbach $\rightarrow$ Limbach. To mnenje je sprejel tudi Ramovš, Steinhauser pa madž. Lendava in nem. Limbach izvaja iz sloven. *Lindava, kar naj bi bilo iz srvnem. *Lindache, Lindâ. Kniezsa trdi, da je slovensko in madžarsko ime iz osnove lędo, nemško ime pa glasoslovno ne more biti izvedeno iz slovenskega, razen če ni ljudskoetimološko popačeno. Bezlaj meni, da je v imenu Lendava ohranjen nosnik pod vplivom madžarskega uradnega imena in da je verjetnejša Steinhauserjeva razlaga (SVI I: 332-333). 
Flisarjev les || F'li:sarof 'le:is, $F^{\prime} l i$ :sarovoga li'sa:, $f F^{\prime} l i$ :sarovon 'le:isi m, mtn gozda; svojilni pridevnik je izpeljan iz priimka posestnika.

Frčkov les || 'Frčkof 'le:is, 'Frčkovoga li'sa:, f'Frčkovon 'le:issi m, mtn gozda; svojilni pridevnik je izpeljan iz hišnega imena.

Linkašev les || 'Li:nkašof'le:ins, 'Li:nkašovoga li'sa:, v'Li:nkašovon 'le:isisi m, mtn gozda; svojilni pridevnik je izpeljan iz hišnega imena.

Mačkov les || 'Ma:čkof 'le:is, 'Ma:čkovoga li'sa:, v 'Ma:čkovon 'le:issi m, mtn gozda; svojilni pridevnik je izpeljan iz hišnega imena.

Marinkašev les || Ma'ri:nkašof 'le:is, Ma'ri:nkašovoga li'sa:, v Ma'ri:nkašovon 'le:isis m, mtn gozda; svojilni pridevnik je izpeljan iz hišnega imena.

Pintarjev les || 'Pi:ntarof'le:is, 'Pi:ntarovoga li'sa:, f'Pi:ntarovon 'le:isis m, mtn gozda; svojilni pridevnik je iz izpeljan hišnega imena, to pa iz imena poklica pintar 'sodar' iz nem. Fassbinder 'isto'.

Pozvekov les || Poz'vẹ:inkof'le:in, Poz've:ikovoga li'sa:, f Poz'vẹ:inkovon 'le:issi m, mtn gozda; svojilni pridevnik je izpeljan iz hišnega imena.

Putarjev les || 'Pü:tarof 'le:ins, 'Pü:tarovoga li'sa:, f'Pü:tarovon 'le:i্si m, mtn gozda; svojilni pridevnik je izpeljan iz hišnega imena.

Reckov les || 'Rẹ:ịckof 'le:ins, 'Rẹ:ickovoga li'sa:, v'Rẹ:ickovon 'le:insi m, mtn gozda; svojilni pridevnik je izpeljan iz priimka posestnika.

Šavrijev les || 'Ša:urijof 'le:ịs, 'Ša:urijovoga li'sa:, f'Ša:urijovon 'le:insi m, mtn gozda; svojilni pridevnik je izpeljan iz hišnega imena.

Šoštarjev les || 'Šo:uštarof 'le:în, 'Šo:uštarovoga li'sa:, f'Šo:uštarovon 'le:issi m, mtn gozda; svojilni pridevnik je iz hišnega imena, to pa iz imena poklica šóštar 'čevljar' iz srvnem. schuohster 'isto', nem. Schuster 'isto' (SES: 745; DLS: 222).

$*$ Lulik $\Rightarrow$

Pri Luliku $\| P_{o}{ }^{\prime} L \ddot{u}: l i k i$, mtn njive in travnika; predložno ime je tvorjeno iz hišnega imena.

Madžarovo || 'Måžarovo -oga, na 'Måžarovon s, mtn njiv; ime je tvorjeno iz priimka Madžár in svojilne pripone -ov; priimek je iz enakoglasnega etnika.

*Marčevo $\Rightarrow$

Na Marčevem \| $N a$ 'Mårčovon, mtn njive, travnika, sadovnjaka in gozda; ime posesti je tvorjeno iz hišnega imena.

$*$ meja $\Rightarrow$

Pri meji || $P r$ ' $m e$ :ji ‘črta, ki ločuje, razmejuje ozemlja zemljišča, parcele' (SSKJ: 537).

$*$ Miškovo $\Rightarrow$

Na Miškovem \| $\mathrm{Na}$ 'Miškovon, mtn njive; ime posesti Miškovo je tvorjeno iz hišnega imena, to pa iz osebnega imena Miško.

Mlinščica || M'li:nščica -e, pr M'li:nščici ž, hdn umetno narejenega pritoka Ledave; ime ustreza apelativu mlínščica 'del potoka ali reke, speljan k mlinu' (SSKJ: 562; Plet. I: 587), izpeljanim iz apelativa mlin < lat. mulīnum, ki je pogosta imenska baza (SVI II: 26).

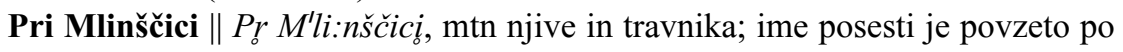
vodnem imenu. 
$*$ most $\Rightarrow$

Pri malem mostu \| $P r$ 'ma:lon 'mo:usti, mtn njive; v imenu se ohranja apelativ móst.

Pri velikem mostu $\| P r$ 'velkon 'mo:usti, mtn njiv in travnika.

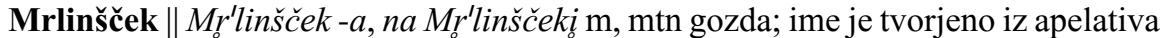
mrlína 'das Aas' (Plet. I: 607); na teh zemljiščih ali v njihovi bližini so nekdaj pokopavali poginule živali.

*njiva $\Rightarrow$

Baraševa njiva || 'Ba:rašova n'jiva, 'Ba:rašove n'jive, na 'Ba:rašovoj n'jivi ž, mtn njive; v imenu se ohranja apelativ njivva 'del zemljišča za gojenje kulturnih, krmnih rastlin' (SSKJ: 685); svojilni pridevnik je iz hišnega imena.

Debeljakova njiva || Debella:kova n'jiva, Debella:kove n'jive, na Debe'la:kovoj $n^{\prime} j i v i$ ž, mtn njive; svojilni pridevnik je iz hišnega imena.

Dolga njiva || 'Du:uga n'jiva, 'Du:uge n'jive, na 'Du:ugoj n'jivi ž, mtn njive; po Ilešiču (1950: 38) je Dolga njiva osrednje, morda najstarejše in najplodnejše polje v vasi.

Hajdinjakova njiva || Xajdin'ja:kova n'jiva, Xajdin'ja:kove n'jive, na Xajdin'ja:kovoj n'jivi ž, mtn njive; svojilni pridevnik je iz priimka posestnika.

Marinkaševa njiva \| Ma'ri:nkašova n'jiva, Ma'ri:nkašove n'jive, na Ma'ri:nkašovoj n'jivi ž, mtn njive; svojilni pridevnik je iz hišnega imena.

Nemčeva njiva || 'Nẹcova n'jiva, 'Nẹncove n'jive, na 'Nẹncovoj n'jivi ž, mtn njive; svojilni pridevnik je iz hišnega imena.

Putarjeve njive || 'Pü:tarove n'jive, 'Pü:tarovij n'ji:f, f/na 'Pü:tarovij n'jivaj ž mn., mtn njiv; svojilni pridevnik je iz hišnega imena.

Tišlarjeva njiva || 'Tišlarova n'jiva, 'Tišlarove n'jive, na 'Tišlarovoj n'jivi ž, mtn njive; svojilni pridevnik je iz hišnega imena, to pa iz imena poklica iz nem. $\mathrm{Ti}^{-}$ schler 'mizar'.

Ungarjeve njive || 'Ungarove n'jive, 'Ungarovij n'ji:f, na 'Ungarovij n'jivaj ž mn., mtn njiv; svojilni pridevnik je iz hišnega imena.

Žeponova njiva \| Že'ponova n'jiva, Že'ponove n'jive, na Že'ponovoj n'jivi ž, mtn njive; svojilni pridevnik je iz hišnega imena.

Ograd || 'Ograt -da, v'Ogradi m, mtn njive in travnika; ime ustreza apelativu ógrad 'plot, ograja' (ESSJ I: 168).

$*$ oreh $\Rightarrow$

Pri orehu || Pr o'rejĭ, mtn njive; v predložnem imenu se ohranja dnd ôreh 'Juglans regia' (ESSJ II: 253; SVI II: 63).

*Perš $\Rightarrow$

Pri Peršu \|| $\operatorname{Pr}$ 'Perši $i$, mtn njive; predložno ime je tvorjeno iz hišnega imena.

Pintarjevo || 'Pi:ntarovo -oga, na 'Pi:ntarovon s, mtn njive; ime je tvorjeno iz hišnega imena Píntar, to pa iz imena poklica iz nem. Fassbinder 'sodar'.

$*$ plot $\Rightarrow$

Za plotom || Za p'lo:uton, mtn njive; v predložnem imenu se ohranja apelativ plót 'ograja' (ESSJ III: 61).

Poldekovo || 'Po:ldekovo -oga, na 'Po:ldekovon s, mtn njive in travnika; ime je tvorjeno iz hišnega imena, to pa iz osebnega imena Pólde. 
Pusta || 'Pu:sta -e, f'Pu:sti ž, tpn zaselka in mtn njiv ter travnika v tem zaselku; ime ustreza apelativu pústa 'neobdelana zemlja', ki ga Bezlaj izvaja iz osnove *pûstb 'neobljuden, nerodoviten, zapuščen' (SVI II: 127).

*pušča $\Rightarrow$

V puščah \| $F^{\prime}$ pü:ǐščaj, mtn njive; v imenu se ohranja nar. oblika apelativa púšča 'neobdelana zemlja' (ESSJ III: 137, pod pustíti; SVI II: 128, 129).

Rastike \| Ras'tike, Ras'ti:k, v Ras'tikaj ž mn., tpn zaselka, tudi mtn njiv, travnikov, vinograda in gozda $\mathrm{v}$ tem zaselku; $\mathrm{v}$ imenu se ohranja množinska oblika apelativa rastika 'rastlina, trava' (ESSJ III: 152, pod rásti).

\section{* Riftar $\Rightarrow$}

Pri Riftarju \| $P r$ 'Riftari, mtn njive; ime je tvorjeno iz hišnega imena Riftar.

Riftarjevo || 'Riftarovo, 'Riftarovoga, na 'Riftarovon s, mtn njiv in travnika; ime posesti je tvorjeno iz hišnega imena Riftar in svojilne pripone -ov.

*rom $\Rightarrow$

Ober roma || 'Ober 'roma, mtn njive in travnika nad domačo hišo; v imenu se domnevno ohranja apelativ hràm 'kmečka hiša, navadno z gospodarskimi poslopji' (SSKJ: 282); Snoj (2003: 210) besedo izvaja iz stcslovan. xramb 'hiša, šotor, tempelj', pslovan. *xôrmъ (ali *xörmъ) s prvotnim verjetnim pomenom * ‘iz živalskih kož narejen šotor'.

Za romom $\| Z$ a'rọmon, mtn njive in travnika za domačo hišo.

Rompovci || 'Ro:mpofcli, z 'Ro:mpovec, v'Rọ:mpofci in $v$ 'Rọ:mpofcaj m mn., tpn zaselka, tudi mtn njive, travnika, sadovnjaka, vinograda in gozda; v imenu se ohranja apelativ rámpa 'zapornica', kar je izposojenka iz nem. Rampe, to pa iz frc. rampe 'rampa, ograja' (SES 601); zapornica v tem zaselku je v času AvstroOgrske ločevala avstrijski in ogrski del monarhije.

*sliva $\Rightarrow$

Pri slivah || Pr s'livaj, mtn njive; v predložnem imenu se ohranja dnd slíva 'Prunus'.

*srce $\Rightarrow$

V srcih || $F s_{o}^{\prime} c a: j$, mtn njive; v predložnem imenu, verjetno nastalem po značilni obliki zemljišča, ki je v primerjavi z okoliško parcelizacijo srčaste oblike, se ohranja apelativ srcé.

$*$ Šajt $\Rightarrow$

*štala

Pri Šajtu || $P r$ 'Šajiti, mtn njive; predložno ime je tvorjeno iz hišnega imena.

Za štalo || Za št tålo, mtn njive; v predložnem imenu se ohranja apelativ štála, izposojenka iz srvnem. stal, -lles 'prostor za živino, hlev' (DLS: 227) ali it. stalla 'ograjen in pokrit prostor za živino' (ESSJ IV: 105); po Snoju (2003: 739) je beseda prevzeta iz it. stalla 'hlev', izposojenke iz germ. *stala-, iz česar je stvnem. stal 'hlev'.

Šulpan || 'Šu:lpan - a,f'Šu:lpani m, mtn njiv; ime je nejasno.

*travnik $\Rightarrow$

Hartnerjevi travniki \|| 'Xa:rtnerovi t'ra:vniki, 'Xa:rtnerovij t'ra:vnikof, na 'Xa:rtnerovij t'ra:vnikaj m mn., mtn travnikov; v imenu se ohranja množinska oblika apelativa trávnik; svojilni pridevnik je iz priimka. 


\section{Pintarjevi travniki || 'Pi:ntarovį t'ra:vniki, 'Pi:ntarovij t'ra:vnikof, na 'Pi:ntarovij} $t^{\prime}$ ra:vnikaj $\mathrm{m}$ mn., mtn travnikov; svojilni pridevnik je iz hišnega imena Píntar, to pa iz imena poklica iz nem. Fassbinder 'sodar'.

$*$ uta $\Rightarrow$

Za uto $\| Z a$ 'ütof, mtn njive; v predložnem imenu se ohranja apelativ úta 'lopa', izposojenka iz stvnem. hutt(e) $a$ ali srvnem. hütte 'koča, šotor, stojnica, talilnica rude' (ESSJ IV: 270).

Vaniševo || 'Va:nišovo -oga, na 'Va:nišovon $\mathrm{s}$, mtn njive in travnika; ime posesti je tvorjeno iz hišnega imena in svojilne pripone -ov.

Varaš || 'Va:raš - $a, v^{\prime}$ 'Va:raši m, tpn zaselka; ime ustreza apelativu váraš 'mesto', izposojenki iz madž. város, váras 'mesto' (ESSJ IV: 283).

Vas || 'Vẹ:is -i, v'Vẹ:isi ž ž, tpn zaselka, tudi mtn njiv, travnikov in sadovnjaka v tem zaselku; ime ustreza apelativu vás 'navadno manjše naselje, katerega prebivalci se ukvarjajo večinoma s kmetijstvom' (SSKJ: 1491).

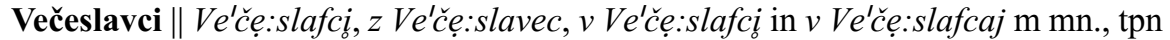
razloženega naselja na obeh straneh Ledave ob cesti Gederovci-Sotina; 1365 Wenchezlaufolua (Venčeslavova vas), 1366 Gyurgfiamyklowsfalua (Jurijevega Mikloša vas) al. nom. Gezloufalua (Česlavova vas) ${ }^{7}$ (Zelko 1982: 92), 1698 Veczezlovecz, Vecsészlavecz (Zelko 1996: 75), 1874 Sessldorf oder Vecsislavecz (Rajšp - Serše 2001: 8; I-6); Večeslavčarje || Ve'čẹe:slafčarge; večeslavski $\|$ ve'čẹ:slafski.

Vince $\|{ }^{\prime} V i: n c e-a, n a{ }^{\prime} V i: n c i$ s, tpn zaselka, tudi mtn njiv, travnika in gozda $\mathrm{v}$ tem zaselku; ime je manjšalnica iz apelativa víno.

$*$ vrh $\Rightarrow$

Rakov vrh || 'Råkof'vr:, 'Råkovoga 'vr:ja, na 'Råkovon 'vr:ji m, mtn njive, vinograda in gozda; $v$ imenu se ohranja apelativ vŕh.

*zavetje $\Rightarrow$

Za zavetjem $\| Z a^{\prime}$ za:vitjon, mtn sadovnjaka; $\mathrm{v}$ imenu se ohranja nar. apelativ závitje 'zavetje' (Novak 1996: 176; ESSJ IV: 395, pod zavet I; prim. tudi véti I) za knjiž. zavétje 'kraj, prostor, zavarovan pred vetrom' (SSKJ: 1639).

Žlak || Ž'låk - $a$, na Žlåkio m, mtn njiv; ime ustreza apelativu žlàk 'spodnji, nasuti rob zlasti vinograda' ali 'kolosek, pot; čistina, jasa', izposojenki iz srvnem. slac 'širok jarek na vznožju vinske gorice, kamor odteka voda; pot; s poseko narejena čistina, jasa' (ESSJ IV: 462; Novak 1996: 183).

Zbrana imena so zvečina izvorno slovenska, $\mathrm{v}$ podstavi nekaterih pa so tudi v časovno različnih jezikovnozgodovinskih obdobjih prevzete besede iz stičnih jezikov, zlasti iz nemščine. Najstarejše občnoimenske nemške izposojenke, ki so se v prekmurščini tudi polastnoimenile, segajo v starovisokonemško oz. alpskoslovansko obdobje. S stališča sodobnega slovenskega knjižnega jezika so označene kot narečne (uta), narečne vzhodne ( $r a b a$ ) ali nižje pogovorne (britof). Srednjevisokonemške izposojenke (do 13. stoletja) in poznejše izposojenke, predvsem iz bavarske

7 Morda sta s tema imenoma označeni naselbini Pertoča in Večeslavci; Gezlou (Česlav) je okrajšana oblika od Večeslav (Zelko 1982: 92). 
nemščine, so bile sprejete v knjižni jezik kot nižje pogovorne (štala) ali narečne vzhodne (žlak), nekatere pa živijo samo v narečju (gres). Iz madžarščine je prevzeta beseda varaš, zelo stara romanska izposojenka je mlin, brajda je langob. izvora.

\section{Jezikovne značilnosti imen ter njihova tipologija}

2.1 Obravnavano področje se uvršča h goričkemu prekmurskemu podnarečju, kar se odraža tudi v glasoslovnih in oblikoslovnih značilnostih zbranih imen. Narečnost na glasoslovni ravnini se kaže v odrazu $\ddot{u}$ za $u$ in $i$ v položaju pred $l-{ }^{\prime} C u ̈ r e k$, Za 'ütof, Na go'müli, v odrazu $u$ : u za $l$ - 'Du:uga n'jiva, v odrazu e :i za stalno dolgi polglasnik: 'Ve:is, e:i za stalno dolgi jat: B're:ik, 'De:idijovo in o:u za stalno dolgi $o-P r$ 'velkon 'mo:usti, Za p'lo:uton; staroakutirani $a$ v zadnjem in nezadnjem besednem zlogu je ostal kratek in zaokrožen: Za g'råbami. V zapisanih imenih je -ljotrdel v -l- - 'Cüncel, -nj- je ohranjen: Na krto'fi:njeki, enako tudi -šč- - D'vo:urišča, Mrlinšček. $v$ v položaju pred nezvenečim nezvočnikom ter na koncu besede izgubi zven in se premenjuje s $-f$ - 'Pi:ntarof $B^{\prime} r e: i n k, F s r^{\prime} c a: j, j$ se v položaju pred zadnjimi

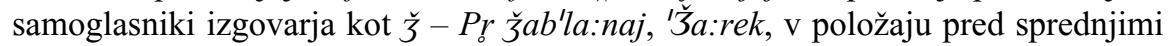
samoglasniki pa kot $g-G e^{\prime} r u: z a l e n$ ali $k$ (v položaju za nezvenečim soglasnikom): 'گ̌o:uške. Prim. še: -vi- > -j- - Bo'ro:jca, $x \sim j \sim \emptyset-P r o$ 'rejji, 'Råkof'vr:, $-m>-n-N a$ 'Mårčovon, Za 'za:vitjon.

Narečnost na oblikoslovni ravnini se kaže v končnici $-i$ v mest. ed. m. sp.: Na b're:igi, Pr 'ك̌a:rki, v posplošeni mestniški množinski končnici -aj $(<-a x)-P r$ క̌ab'la:naj, v moškospolski mestniški pridevniški končnici -on za knjižno -em - na 'Sikašovon B're:igi in ženskospolski mestniški pridevniški končnici -oj za knjižno

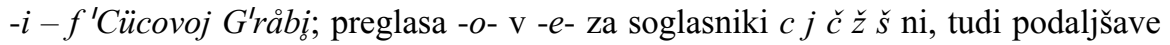
osnove na $-r$ ne.

2.2 Zbrana zemljepisna imena so enobesedna, in to samoedninska, npr.: Bo'ro:jca, B're:ink, 'Cürek, G'rẹ:ins, 'Ograt, 'Pu:sta, ali samomnožinska, npr. Č'rẹte, 'Go:mblce, $G^{\prime} r a: j k e, K_{o}^{\prime}{ }^{\prime} \check{c} o: n j e$, saj se nanašajo na zemljepisni objekt, pojmovan kot celoto, ${ }^{8}$ ter večbesedna.

Enobesedna so netvorjena, npr. 'Bojna, B're:ik, 'Vẹ:is, ali tvorjena: (a) izpeljanke z moškospolskimi, ženskospolskimi in srednjespolskimi priponami: - $\emptyset$ - 'Ograt, -šček - Mr'linšček; - a - 'Pu:sta, -ica - Bo'ro:jca, M'li:nščica, -ice - 'Go:mblce, -ike - Ras'tike, -ovine - Kr'čọ:nje (<Krčevine); -ce - 'Vi:nce, -išča - D'vo:urišča, -je 'گ̌o:uške; (b) konverzija/posamostaljeni pridevniki: Cerk'veno, 'Ledafsko, 'Må̆̌arovo. Večbesedna imena so: (1) samostalniške besedne zveze s pridevniškim določilom: (a) kakovostni pridevnik + samostalnik: 'Du:uga njiva; (b) svojilni pridevnik na -ov, -in + samostalnik: Xor'va:tove go'rice, 'Filipovo '̌̌o:uške, 'Ba:rin 'le:iss; (2) besedne zveze iz samostalnika (ali samostalniške besedne zveze z levim pridevniškim določilom) in predloga: Na b're:igi, 'Ober 'roma, P're:ink F'likaša, Pro o'reji, Za b'ra:jdami ; Pr

8 Gl. Šivic Dular 1988: 231. 
- $\quad$ 'ma:lon 'mo:usti, Pr 'velkon 'mo:ustí; (3) samostalniške besedne zveze z neujemalnim predložnim samostalniškim prilastkom: 'క̌o:uške pr F'likašig.

2.3 Glede na motivacijsko podstavo je zbrana imena mogoče razvrstiti v več pomenskih skupin. Navadno se je namreč polastnoimenilo občno besedje, ki označuje: (1) namembnost, izrabo zemljišča: ('Ro:ganove) go'rice, (Ma'ri:nkašova) n'jiva, 'Ograt, ('Xa:rtnerovi) t'ra:vniki; (2) naravne objekte v bližini; ta imena so večinoma predložna: Za g'råbami, Pr 'Ledavig; (3) umetne objekte v bližini: (a) stanovanjske: 'Ober 'roma, Za 'romon, (b) gospodarske: Za š'tålo, Za 'ütof, (c) sakralne: Pr k'ri:iži, (č) vrsto kultiviranega zemljišča: Za b'ra:jdami, (d) komunikacije: Pr 'ma:lon 'mo:usti, $P r$ 'velkon 'mo:usti; imena te skupine so izključno predložna; (4) umetne

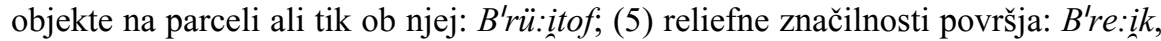
('Ro:ganove) go'rice, (Sa'bo:ulove) g'råbe; Na b're:igi, Na go'müli; (6) kakovost zemljišča; ledinska imena izražajo kakovost poimenovanega zemljišča, zlasti njegove slabosti: 'Pu:sta, F' 'pü:iščcaj; (7) vrsto, značilnost tal; iz nekaterih imen lahko razberemo značilnosti zemljišča, njegovo sestavo: Č'rẹte, G'rẹ:is; (8) način kultiviranja zemljišča; imena kažejo na postopek pri spremembi nekultiviranega zemljišča v kultivirano: Kr'čco:nje; (9) razsežnosti in razmerja v prostoru: (a) razmerje dolg - kratek: 'Du:uga n'jiva; (b) prostorsko razmerje izraža tudi ime $P r$ 'mẹ:ji⿱ ; (10) rastline; imena rastlinskega izvora so vezana pretežno na gozdna drevesa: $B o^{\prime} r o: j$ jca, 'క̌o:uške, manj je imen, poimenovanih po kulturnih rastlinah: 'Vi:nce; $P r o$ o'reji, $P r$ s'livaj; (11) nekdanjo poljsko razdelitev: G'ra:jke, 'Ograt. Zemljišča so pogosto poimenovana tudi po lastniku sosednjega posestva ali domačije; v tej vlogi se največkrat pojavljajo domača hišna imena, in to najpogosteje $\mathrm{v}$ zvezi s predlogom pri-Pr 'Lü:liki, Pr 'Peršĭ, P're:įk F'likaša, ter pripadništvu ali lastništvu (nekdanji ali sedanji lastniki, ki so dali zemljišča $\mathrm{v}$ najem ali zakup); parcele so poimenovane s posamostaljenimi pridevniki: 'క̌o:uškino, 'Frčkovo, 'Va:nišovo, v predložni rabi opravlja to funkcijo predlog $n a-\mathrm{Na}$ 'Mårčovon, $\mathrm{Na}$ 'Miškovon, veliko pa je tudi dvobesednih imen, katerih samostalniška odnosnica ob svojilnem pridevniku označuje predvsem vrsto zemljišča: F'ro:ncof b're:ik, 'Ro:ganove go'rice, 'Mårčove g'råbe, Debe'la:kof'le:is, Xajdin'ja:kova n'jiva, 'Pi:ntarovi t'ra:vniki; opaziti je poimenovanje po lastništvu bližnjih sorodnikov: 'De:idijovo, lastniški značaj pa ima tudi ime Cerk'veno (zemljišče, ki je nekdaj pripadalo Cerkvi). Posamezne parcele so poimenovalno vezane na prisotnost vode: 'Cürek, poimenujejo se tudi po obliki: $F$ $s_{o}^{\prime}{ }^{\prime} c a: j$, 'Go:mblce ter po nekdanjih dogodkih in rabi: 'Bojna, Mr'linšček, 'Ro:mpofci.

\section{$3 \quad$ Sklep}

Ledinska imena so tesno povezana z zgodovinskimi, družbenimi, geografskimi in naravoslovnimi značilnostmi okolja. Zaradi spreminjajočega se načina življenja, opuščanja kmetovanja in vse manjše navezanosti ljudi na zemljo hitro tonejo v pozabo. Danes jih dobro poznajo le še govorci najstarejše generacije, govorci mlajše generacije pa sploh ne več, zato bi jih bilo treba čim prej zbrati in zapisati, dokler je to sploh še mogoče. 


\section{Okrajšave}

Okrajšave jezikov so take kot v Snoj (2003): ben. - beneško, frc. - francosko, furl. furlansko, germ. - germansko, gr. - starogrško, it. - italijansko, knjiž. - knjižno, lat. - latinsko, langob. - langobardsko, madž. - madžarsko, nar. - narečno, nem. - nemško, pslovan. - praslovansko, sloven. - slovensko, srvnem. - srednjevisokonemško, stcslovan. - starocerkvenoslovansko, stvnem. - starovisokonemško. - Drugo: dnd - dendronim, hdn - hidronim, vodno ime, mtn - mikrotoponim, ledinsko ime, tpn - toponim, naselbinsko ime.

\section{Viri in literatura}

Bezlaj 2003 = France Bezlaj, Zbrani jezikoslovni spisi I-II, ur. Metka Furlan, Ljubljana: ZRC SAZU, 2003.

Čop 2002 = Dušan Čop, Gorska, terenska (ledinska) in vodna imena v Sloveniji, Jezikoslovni zapiski 8 (2002), št. 2, 93-108.

DLS = Hildegard Striedter-Temps, Deutsche Lehnwörter im Slovenischen, Berlin: Osteuropa-Institut, 1963.

ESSJ I-V = France Bezlaj, Etimološki slovar slovenskega jezika I-V, Ljubljana: Mladinska knjiga - SAZU - ZRC SAZU, 1976, 1982, 1995, 2005, 2007.

Holsedl 2006 = Zdenka Holsedl, Ledinska in hišna imena v vasi Večeslavci: diplomsko delo, Maribor: Pedagoška fakulteta, 2006.

Ilešič 1950 = Svetozar Ilešič, Sistemi poljske razdelitve na Slovenskem, Ljubljana: SAZU, 1950.

Jakopin idr. 1985 = Franc Jakopin idr., Slovenska krajevna imena, Ljubljana: Cankarjeva založba, 1985.

Koletnik 2007 = Mihaela Koletnik, Krajevna imena v izbranih naseljih občine Rogašovci, Razprave drugega razreda SAZU 20, Ljubljana: SAZU, 2007, 95-114.

Koletnik 2008 = Mihaela Koletnik, O prekmurskih mikrotoponimih, Slavistična revija 56 (2008), št. 2, 75-86.

Majdič 2004 = Viktor Majdič, Ledinska imena zahodnega dela občine Šentjur pri Celju, v: Besedoslovne lastnosti slovenskega jezika - slovenska zemljepisna imena, Maribor: Društvo Pleteršnikova domačija Pišece - SD Slovenije, 2004, 170-180.

Melik 1963 = Anton Melik, Potek poselitve v luči krajevnih imen, v: Slovenija 1, Ljubljana: Slovenska matica, 1963, 307-308.

Merku 2006 = Pavle Merku, Krajevno imenoslovje na slovenskem zahodu, Ljubljana: ZRC SAZU, 2006.

Novak 1996 = Franc Novak, Slovar beltinskega prekmurskega govora, priredil in uredil Vilko Novak, Murska Sobota: Pomurska založba, ${ }^{2} 1996$ [1985, $\left.{ }^{3} 2009\right]$.

Orožen Adamič - Perko 1995 = Milan Orožen Adamič - Drago Perko (ur.), Krajevni leksikon Slovenije, Ljubljana: DZS, 1995. 
Plet. I-II = Maks Pleteršnik, Slovensko-nemški slovar I-II, ur. Metka Furlan, Ljubljana: ZRC SAZU, 2006.

Rajšp - Serše 2001 = Vincenc Rajšp - Aleksandra Serše, Slovenija na vojaškem zemljevidu 1763-1787 7: Opisi, Ljubljana: SAZU, 2001.

Snoj 2003 = Marko Snoj, Slovenski etimološki slovar, Ljubljana: Mladinska knjiga, 2003.

Snoj 2006 = Marko Snoj, O tujkah in izposojenkah v slovenskem jeziku, Slavistična revija 54 (2006), posebna številka, 343-349.

SSKJ = Slovar slovenskega knjižnega jezika, Ljubljana: DZS, 1995.

SVI I-II = France Bezlaj, Slovenska vodna imena I-II, Ljubljana: SAZU, 1956, 1962.

Šekli 2006 = Matej Šekli, Strukturni tipi ledinskih imen v kraju Livek in njegovi okolici, v: Jezikovna predanost: akademiku prof. dr. Jožetu Toporišiču ob 80-letnici, ur. Marko Jesenšek - Zinka Zorko, Maribor: SD Maribor - Ljubljana: SAZU, 2006 (Zora 44), 477-491.

Šekli 2007 = Matej Šekli, Imenje v kraju Šalovci, v: Etnološki raziskovalni tabor Šalovci 2007: zbornik prispevkov, Murska Sobota: Zveza za tehnično kulturo - RC ZOTKS, 2007.

Šekli 2007a = Matej Šekli, Ljudskozemljepisno izrazje v topoleksemih ledinskega imenja na Livškem, v: Razvoj slovenskega strokovnega jezika, Ljubljana: Filozofska fakulteta, 2007 (Obdobja 24), 515-530.

Šekli 2008 = Matej Šekli, Zemljepisna in osebna lastna imena $v$ kraju Livek in njegovi okolici, Ljubljana: Založba ZRC, ZRC SAZU, 2008 (Linguistica et philologica 22).

Šivic-Dular 1988 = Alenka Šivic-Dular, Besedotvorne vrste slovenskih zemljepisnih imen na gradivu do leta 1500, v: Srednji vek v slovenskem jeziku, književnosti in kulturi, Ljubljana: Filozofska fakulteta, 1988 (Obdobja 10), 229-244.

Škofic 2004 = Jožica Škofic, Zemljepisna lastna imena na Dobravah med dolinama Lipnice in Savne, v: Besedoslovne lastnosti slovenskega jezika - slovenska zemljepisna imena, Maribor: Društvo Pleteršnikova domačija Pišece - SD Slovenije, 2004, 60-73.

Torkar 2003 = Silvo Torkar, $\mathrm{K}$ nastanku in pomenu nekaterih zemljepisnih imen v Baški dolini, Slavistična revija 51 (2003), št. 4, 429-442.

Torkar 2008 = Silvo Torkar, Slovenska zemljepisna imena, nastala iz slovanskih antroponimov, Slavistična revija 56 (2008), št. 2, 17-29.

Unuk 2004 = Drago Unuk, Zemljiška imena v Črešjovi grabi in Strmcu (Stoperce v Halozah), v: Besedoslovne lastnosti slovenskega jezika - slovenska zemljepisna imena, Maribor: Društvo Pleteršnikova domačija Pišece - SD Slovenije, 2004, 194-201.

Zelko 1982 = Ivan Zelko, Prekmurje do leta 1500, Murska Sobota: Pomurska založba, 1982 (Historična topografija Slovenije I).

Zelko 1985 = Ivan Zelko, Prekmurska ledinska imena - in primerjava s panonskoslovenskimi imeni, Slavistična revija 33 (1985), št. 4, 459-465.

Zelko 1996 = Ivan Zelko, Zgodovina Prekmurja, Murska Sobota: Pomurska založba, 1996. 


\section{Toponyms in Večeslavci}

\section{Summary}

This article presents toponyms collected in Večeslavci in the Goričko region. The collected names reflect phonological and morphological characteristics of the Goričko subdialect of Prekmurje. They are sorted into semantic groups by their motivational basis. Proper nouns developed from common nouns signifying (1) land use: (Ma'ri:nkašova) n'jiva 'Marinkaš' field', 'Ograt 'garden'; (2) nearby natural features: $P r$ 'Ledavi 'by the Ledava River'; (3) nearby manmade structures: (a) residential: Za 'romon 'behind the house', (b) farming: Za šltålo 'behind the stall', (c) sacral: Pr k'ri:ži 'by the cross', (d) type of cultivated land: Za b'ra:jdami 'behind the (vineyard) trellises', (e) communications: Pr' velkon 'mo:usti 'by the big bridge'; (4) manmade structures on lots or next to them: B'rü:itof 'cemetery'; (5) surface relief features: B're:ik 'bank', Na go'müli 'on the tumulus'; (6) land quality: 'Pu:sta 'barren'; (7) land type or characteristic: Č'rẹte 'marshland', G're:is 'silt'; (8) manner of cultivating the land: $K r_{0}^{\prime}$ 'co:nje 'grubbing'; (9) spatial dimension and relation: Du:uga n'jiva 'long field', Pr 'me:ji 'by the border'; (10) vegetation: Bo'ro:jca 'juniper', 'Vi:nce 'grapevines'; and (11) former field division: G'ra:jke 'fence'. Land was also often named after the owner of the neighboring property or farm: $\operatorname{Pr}^{\prime}$ 'Perš $i$ 'by Perš' as well as affiliation or ownership: 'گ̌o:uškino 'of Jožko', $\mathrm{Na}$ 'Miškovon 'at Miško's'; there are many two-word names in which a nominal head alongside a possessive adjective primarily expresses the type of land: Debe'la:kof'le:is 'Debelak's woods', Xajdin'ja:kova n'jiva 'Hajdinjak's field', 'Pi:ntarovi t'ra:vniki 'Pintar's meadows'. The names of some lots were connected to the presence of water: 'Cürek 'jet of water', shape: 'Go:mblce 'mound', and former events or use: 'Bojna 'battle', Mr'linšček 'carcass dump'.

The majority of names are Slovenian in origin, but the bases of some are also words borrowed from contact languages in various historical linguistic periods, especially from German. They are well-known by older and middle-aged speakers, but less familiar to young people. Because of the changing lifestyle, abandonment of farming, and decreased attachment to the land, these names are gradually being forgotten, and so they should be collected and recorded as soon as possible, while this is still possible. 